\title{
1. Conceptualizing common political order: an introduction
}

\section{Jarle Trondal}

\section{INTRODUCTION}

With the ever more frequent turbulence in world affairs - exemplified with the rise of a more able and willing Chinese foreign policy, the Syrian war and so on - and with the ever more questioning of the sustainability of the European Union (EU) after the 'Brexit' referendum in 2016, there is a call for understanding the conditions for sustained political order (Ansell et al., 2017; Fukuyama, 2016; Olsen, 2007). There are continuous disputes over 'the legitimate role of democratic politics in society' and, ultimately, 'forms of political association' (Olsen, 2016, 1 and 5). These challenges are not unique to Europe. As in previous campaigns, the US presidential campaign of 2015 and 2016 put forth the question as to what level of government is desired, and it was the then Republican contender and now president, Donald Trump, who consistently rallied against 'big government' (Kristof, 2016). More importantly, so-called failed states accentuate the concern for political order on the global stage. The Syrian people have experienced the complete collapse of political order and are desperately calling for peace, security and justice - the basic ingredients for political order. The significance of political order is often taken for granted during historical periods of stability. During periods of political decay, however, existing political arrangements become subject to contestation, requests for reform and eventually revolution. Periods of unrest sometimes also call for well-known political and organizational solutions. Unfamiliar problems sometimes call for familiar answers. The financial crises that hit Europe in the aftermath of the global financial and economic crisis of 2007/8 illustrated that to understand political order we eventually need to understand how such order emerges, changes and decays (Fukuyama, 2014). It is equally important to understand how organizations, and different modes of organizing, affect decision making, cooperation and conflict, as well as political outcomes. Studies of unstable and transitional political orders, however, are much less attended to in scholarship. Since 
the classic administration school of Luther Gulick (1937), and up to recent public administration and comparative government literature (Olsen, 2010), scholars have largely dealt with settled political orders. This volume aims to contribute to a better understanding of political order formation in an uncomfortably unsettled Europe.

The recent European crises have triggered 'institutional soul-searching' and a raising concern about the nature of res publica (Emery and Giauque, 2014, 24). The challenge of understanding social and political order, however, endures in the social sciences (Elster, 2007; Waldo, 1992, 149). Unveiling social order involves disentangling causes of order formation and distortions (e.g. Bartolini, 2005; Fukuyama, 2014; March and Olsen, 1989; Padgett and Powell, 2012), unravelling the consequences of order formation - especially how it challenges already existing orders (e.g. Olsen, 2007; Skowronek, 1982) - and suggesting how social order can be conceptualized (e.g. Stinchcombe, 1987). Perhaps unsurprisingly for a political system in the making, and as a non-stop institutional building site (Olsen, 2010), the institutional soul-searching is particularly intense in the EU. This book discusses ways to conceptualize emergent political order and gives empirical examples from three laboratories of political order formation:

1. Political order at the international level: Part I of the book offers a chapter on the study of international administration. The succeeding empirical cases offer studies of the troublesome rise of independent international administration, that is, the establishment of an increasingly independent and autonomous international and supranational administration, triggering important questions concerning supranational accountability. The cases applied are the International Atomic Energy Agency, the European Union administration (including the European Commission, EU agencies and domestic agencies), the European Parliament and the European Ombudsman.

2. Political order at a meso- or, as used in this book, macro-regional level: Part II of the book offers a chapter on the phenomenon of macroregional strategies and macro-regions in large-scale forms of regional integration, such as the EU, blending theoretical perspectives from political science, spatial planning and geography. The attribute 'macro' refers to the fact that these 'regions' are construed at an intermediate level between the constituent parts of regional integration, for example, the member and partner states on the one hand and the overarching regional level, that is, the EU, on the other. The succeeding empirical cases include studies of transnational cooperation induced by EU macro-regional strategies as well as a survey-based analysis of the 
governance architecture set up by the EU Strategy for the Baltic Sea Region. In contrast to EU-level or local-level political order, EU 'macro-regionalism' is only 'emerging' at best, and observations are treated in a cautious manner. A macro-regional common political order in the EU is still experimental in nature and in stati nascendi at most (Gänzle and Kern, 2016).

3. Political order at the local level: Part III of the book offers a state-ofthe-art chapter on governance of inter-organizational relations at the local level with a strong focus on Norway and the Nordic countries. Local and regional governments all over Europe seem to encounter an increasing number of challenges connected to scale and scope. Many local and regional governments are too small to be able to provide public services efficiently, while limited territorial scope poses problems for reaching solutions related to border-crossing issues. Thus, local and regional governments engage more extensively and intensely in arrangements to coordinate across sectorial, territorial, functional and administrative boundaries. Many of these arrangements are highly formalized as inter-organizational organizations (IOOs), designed to enhance coordination among local authorities and between local authorities and other organizations, constituting a new political order at the local level. The two ensuing empirical cases focus on how this new political order affects the 'old' democratic and operative institutions, while the final case examines the breakdown of a political inter-municipal cooperation.

Some conceptual terms are worth outlining briefly:

- Order suggests a relatively stable arrangement of institutions that are fairly formalized and institutionalized with respect to who does what, when and how.

- Political suggests that these institutions are both entitled to and able to (contribute to) initiate, decide and implement public policy.

- Common suggests that these political institutions fulfill at least three criteria: (i) they are fairly independent of pre-existing institutions, (ii) they are relatively integrated and cohesive internally and not fragmented and loosely coupled, and (iii) they are reasonably able to influence and challenge political processes within other political institutions - thus turning the order into a common 'one'.

These terms will be further elaborated below. However, to illustrate briefly: In a European context a common EU order would suggests that it is relatively independent of member-state governments, that it is 
fairly integrated internally (within and among the key EU institutions), and that EU institutions are somehow able to co-opt member-state institutions - thus ultimately challenging their political and administrative (not necessarily their constitutional) sovereignty. It is important to note, however, that an 'order' does not suggest political institutions that are perfectly integrated, completely coordinated and impeccably independent. They are imperfectly so. The research question is to what extent new political institutions rise into some kind of 'common' order, and the conditions under which this may occur.

In sum, the notion of common political order suggests a fairly independent, integrated and influential set of institutions that allocate 'authority, power, information, responsibility, and accountability' (Olsen, 2016, 3). This introductory chapter is presented as follows: the next section outlines a research agenda on political order formation by suggesting a public administration approach. The following sections suggest conceptual dimensions that are used in this book for unraveling political order and make a plea for why such an endeavor is worthwhile. The final section then outlines the contents of the book.

\section{THE RESEARCH AGENDA}

A vast literature on state building has demonstrated how the formation of new political orders tends to involve a delicate balancing act between creating central action capacities and addressing concerns for local autonomy (Rokkan, 1999). More recently, studies have suggested that the rise of common institutions at the international level may profoundly transform political order at the national level. For example, studies advocate that international bureaucracies profoundly influence world politics (Biermann and Siebenhüner, 2009), affect power distributions across various levels of government (Egeberg and Trondal, 2009), and transform domestic democratic governance (Keohane et al., 2009). Nevertheless, existing research is inconclusive as regards the extent to which international political orders transform basic logics of pre-existing national, regional and local political orders. One reason for this may be that gulfs persist between social science sub-disciplines, such as public administration and organization theory (March, 2009) as well as comparative public administration scholarship and organization studies (e.g. Trondal, 2016).

There have been three generations of research on political order to date, and this book is part of the third generation of study. Briefly sketched, the first generation of study largely saw domestic political orders as closed systems of governance - treating phenomena external to the domestic 
government as residual categories (see Wilson, 1989). The study of public administration has also largely been limited to the study of domestic administrative systems, notably reforms and politics within domestic ministries and agencies (e.g. Christensen and Lægreid, 2007). Studies of state formation in Europe represent one example of this body of literature (Rokkan, 1999). A second generation of study directed attention to how international institutions affect political order at the national level of government. Research focus shifted towards a transition from an inherently Westphalian political order based on territorial organization of authority to a post-Westphalian order characterized by a restructuring of political authority towards a new (EU) center (Bartolini, 2005; Egeberg, 2006), and a conversion from territoriality to institutionalized, multilevel governance (Ansell and Di Palma, 2004; Hooghe and Marks, 2001). From the late 1960s onwards, a growing literature on administrative integration emerged in the wake of European integration. Studies of public administrations discovered the partial embedment of domestic administrative systems in international executive orders and hence the multilevel character of domestic executive systems. Early scholarly contributions on administrative integration aimed to understand how the domestic-international distinction became blurred due to the 'intermingling of national and international bureaucrats' (Scheinman, 1966, 751). Reflecting this second generation of study, Rosenau (1969, 46) defined order formation as a penetrative process whereby 'members of one polity serve as participants in the political process of another'. One argument advanced within this literature was that the 'descriptions of the [EU] Community as "above", "alongside" or "outside" the member states were useless oversimplifications' (Pag, 1987, 446), highlighting 'bureaucratic inter-penetration' across levels of governance (Rosenau, 1969; Scheinman, 1966). More recently, the interpenetration of political orders is perhaps most successfully captured by the multilevel governance (MLG) approach (Hooghe and Marks, 2001). The MLG approach saw the European political order as a polymorphic system that integrates governance levels into a complex marble cake consisting of a patchwork of separate but interconnected political institutions at different levels of authority (Bulmer, 2008, 173).

As already indicated, this book subscribes to the third generation of study on political order formation by highlighting the administrative basis of common political order formation and the significance of organization for understanding how political order develops and works. To do this, it will integrate several strands of literature and particularly invite the public administration literature to the study of political order formation. This entails also a 'public administration turn' in the study of political order formation. In short, this volume aims to redirect research in the 
field of political order formation somewhat towards public administration studies by asking public-administration-style questions and using public administration toolkits to answer them, as well as by using public administration as a field of empirical enquiry.

\section{PUBLIC ADMINISTRATION AND THE STUDY OF POLITICAL ORDER}

One enduring challenge in conceptualizing political order is to establish meaningful categories that capture essential and enduring characteristics of such an order (e.g. Fukuyama, 2016, 222). Our starting assumption is therefore that adequate analytical categories to classify contemporary political order should offer more empirical variation between rather than within categories. Acknowledging that both analysts and practitioners face problems of meaningful categorization that captures essential aspects of social order in general (Dahlström et al., 2012; Painter and Peters, 2010, 6; Waldo, 1992, 37), and political order in particular, this book suggests a conceptual frame through which such order may be understood. Examples of less meaningful categories are those suggesting that institutions are sui generis and not comparable to any other. Such concepts thereby are not generalizable across time and space and easily prevent the accumulation of general knowledge. Early examples of this were the neo-functionalist approaches to European integration (Haas, 1958) and the contemporary ideas of so-called new intergovernmentalists that describe, among other things, agencies at the EU level as 'de novo bodies' (Bickerton et al., 2015).

Putting the emphasis on emerging structures is an attempt to rectify the ongoing debate about the nature of emergent polities; our approach is to put the administrative dimension of political order formation at center stage. There are two key reasons for doing so. The first is that administrations represent the action capacities for emergent political orders. Without administrations, public policies will not be initiated, drafted nor implemented (Fukuyama, 2014). Moreover, good living conditions and social well-being in general tend to characterize societies governed by 'impartial' public bureaucracies (Rothstein, 2012). So, administrative capacities are central for making 'living' political orders. Second, the administrative dimension is by and large neglected in studies of political order formation (e.g. Rokkan, 1999). In the EU context - the most recent example of political order formation in Europe - the administrative dimension has been largely neglected by leading theoretical approaches, such as constructivist perspectives (Checkel, 2005), intergovernmentalism (Moravcsik, 1998), and multilevel governance (Hooghe and Marks, 2001). 
Advancing a public administration approach to the conceptualization of political order formation, this book follows a strand of thought from early neo-functionalism, where integration of bureaucratic elites was considered essential for European integration (Haas, 1958, 16), to recent advances in neo-functionalist work, by emphasizing how organizations and ways of organizing may bias such processes (Niemann, 2006, 280; Niemann and Schmitter, 2009, 55; Sverdrup and Trondal, 2008). The ambition of this book is thus twofold:

- First, it offers a conceptual frame that takes the 'administrative dimensions' seriously in our understanding of political order formation.

- Second, it brings empirical examples of emergent political orders. These are illustrated by the rise of international administration, the emergence of macro-regional cooperation between the EU, its member as well as partner states (including subnational authorities and other stakeholders, such as interested civil society organizations or institutions of regional cooperation), and finally by the rise of inter-municipal cooperation at the local level within European states.

Despite attaching focal attention to the administrative dimensions of order formation, 'public administration' is not analyzed in isolation - as an 'intellectual wasteland' (Eulau, 1977, 421) - but rather as a set of capacities that mobilize systematic bias in the production of public policy (Arellano-Gault et al., 2013, 154; Gaus, 1950, 168; Schattschneider, 1975). Analyzing enduring patterns and dynamics of the administrative capacities of emergent political orders is essential in our understanding of how public policy is shaped and executed. The public administration approach is thus also an idea of political organization.

Two contemporary scholarly concerns underpin the relevance of choosing such a focus. First, there is a broader theoretical interest behind analyzing the patterns and dynamics of administrative systems. This theoretical agenda relates to the challenge that the emerging EU administrative system poses to the sub-discipline of public administration, which has been largely locked in 'national laboratories' (Christensen and Lægreid, 2011; Verhoest et al., 2012). Theoretical lessons from social sciences are often affected by the empirical laboratories available to scholars. The domain of public administration is no exception to this. Theoretical advances may thus be gained by challenging methodological nationalism. As new forms of political order emerge, they need to be appropriately analyzed and interpreted in view of the changes they imply for bureaucratic systems and public policy. 
Second, the public administration approach directs our attention towards the role that administrative structures play in the development of novel institutional configurations. The more the EU is involved in policy coordination and implementation, the more important become issues of administrative interaction between the involved political levels - if only because the EU lacks an administrative basis to conduct 'supranational' policies independently from member states' administrative systems (M.W. Bauer, 2006; Bauer and Becker, 2014; Heidbreder, 2011). This line of research emphasizes patterns of integration of public administration - not its outcome. One early contribution to this research avenue was an 'Italian law school' studying administrative engrenage (Cassese, 1987; Chiti, 2004; Franchini, 2004; Berlin et al., 1987). Contemporary public administration research has similarly been preoccupied with understanding the European administrative capacity building (Egeberg, 2006; Rittberger and Wonka, 2011) and the interconnected nature of the European public administration (Curtin and Egeberg, 2008; Egeberg, 2010; Egeberg and Trondal, 2009). Illustrative of the latter approach, the European administrative system has been conceived of as a multilevel and nested network administration, though sometimes only loosely coupled (Benz, 2012), where institutions at different levels of government 'are linked together in the performance of tasks' (Hofmann and Turk, 2006, 583; see also Eising and Kohler-Koch, 1999).

Despite successful advances in conceptualizing the EU administrative system (Bauer and Trondal, 2015a), we argue that two challenges plague contemporary public administration scholarship. First, public administration as ONE sub-discipline (Raadschelders, 2011) has paid scant attention to wider debates on how administrations affect the rise and decay of political order (Fukuyama, 2014). This literature has failed to acknowledge how shifting features of the state - such as agencification and subsequent networking of agencies - coexist with the rise of novel forms of multilevel administrative 'patterns' (Danielsen and Yesilkagit, 2014; Egeberg, 2006; Martens, 2010; Trondal, 2014). Much public administration literature has neglected that ways of organizing public policy at one level may bias and 'lock in' ways of making public policy across levels. The administrative realities of the EU - perhaps with the exception of work concerning the European Commission - remains under-studied outside EU studies, even though it has received increased academic attention in recent years (Egeberg, 2006; Ellinas and Suleiman, 2012; Kassim et al., 2013; Trondal, 2010; Wille, 2013). Public administration scholars have at best imperfect and partial understandings of how the European administration functions, how bureaucratic interactions occur horizontally and vertically among various political layers, how administrative structures across 
levels are developing, how precisely supranational administrative actors cultivate and use resources, and how national and subnational bureaucratic structures and actors adapt to and exploit respective constellations. From an administrative science perspective it is of great importance to come to grips with how administrations form political order.

\section{CONCEPTUAL DIMENSIONS}

During the last decade, the EU has served as one of the most important research laboratories for advancing our understanding of political order formation. It is thus natural for this book to build our conceptual apparatus from this field of scholarship. One main thread in this literature has been the multilevel nature of the emergent EU polity (Marks, 1993; Piattoni, 2010). Referring to the EU as a system of multilevel governance has become so colloquial that the term often is either 'stretched' (Sartori, 1970) or used metaphorically thereby collapsing its analytical value. This has contributed to making the mechanisms which fuel polity formation in the EU poorly understood.

This book proposes that a 'level' refers to the existence of separate and relatively independent sets of institutions, rules, procedures and personnel. Multilevel orders thus entail that a new 'platform' emerges that interlinks these items at the national level with parallel items at the level above. This platform of items consists of the paradoxical mix of institutional independence and institutional interconnectedness across levels of authority. It consists of separate institutions (such as the European Commission) that are able to act relatively independently from member-state governments and at the same time having an institutional interconnectedness between the very same institutions (March, 1999). Already acknowledged by the multilevel governance literature, understanding the dynamics of this paradoxical mix - of system independence and interdependence - is essential in order to gain an adequate understanding of the multilevel character of the EU polity (Hooghe and Marks, 2001; Marks et al., 1996a).

A core part of the literature on the European administrative system has centered on the emergence of a multilevel administrative system (MLA) (Trondal and Peters, 2013). A two-dimensional debate can be discerned in this scholarship. First, a political science debate that seeks to theoretically conceptualize (Benz, 2012; Hooghe and Marks, 2001; Marks, 1993) - if not to theorize (Piattoni, 2010) - multilevel governance (MLG) more broadly, and, second, a more recent public administration debate that aims to understand the EU as a multilevel administrative system (MLA) (Bauer and Trondal, 2015b; Egeberg, 2006; Trondal, 2007; Benz, 2015). Moreover, 
we can identify basically two waves of 'MLA' scholarship (hereby termed 'MLA I' and 'MLA II'). This study draws attention to the second surge of research ('MLA II').

- 'MLA I': The first wave of research emphasized convergence of administrative systems and policies (Olsen, 2007). This research measured MLA by its outcomes - which were more convergent administrative forms, practices and ways of doing things. This research developed from the fields of comparative government and comparative public administration, studying for example origins and spread of common administrative traditions (Knill, 2001; MeyerSahling and Yesilkagit, 2011) and public management practices (Christensen and Lægreid, 2011). 'MLA' was conceived of as featuring the convergence of administrative systems around some shared forms, organizational standards and values. One early contribution to this strand of research defined - in the context of the EU - 'MLA' as European administrative convergence, or the 'convergence on a common European model' (Olsen, 2003, 506). One example is the seminal study of national coordination of EU policy by Kassim et al. (2000). They basically examined degrees of convergence of coordination arrangements in EU member states. Amoretti and Musilla (2011) have more recently showed how e-government tools create shared and integrated digital administrative architectures in Europe. Several examples along the 'new governance' research track could be added.

- 'MLA II': A second and more recent line of research conceives of 'MLA' as featuring an emergent common administrative order in Europe through the development of new institutional constellations and configurations (Benz, 2015; Heidbreder, 2015). This second line of research emphasizes new patterns or processes of integration of public administration - not its outcome. Research has been preoccupied with both understanding European administrative capacity building (S. Bauer, 2006; Egeberg, 2006; Rittberger and Wonka, 2011), and understanding the interconnected nature of the European public administration (Curtin and Egeberg, 2008; Egeberg, 2010; Egeberg and Trondal, 2009).

How, then, can one recognize political order if it occurs? Following the second wave of 'MLA' research ('MLA II'), three analytical dimensions have been underlined for analysis in this literature: institutional independence, integration and influence. Political order would thus emerge if new institutions emerge that are relatively independent, fairly integrated, and/or 
somewhat able to influence and challenge other political institutions. Most importantly, perhaps, is the requirement of institutional independence.

\section{Independence}

First, political order involves institutionalizing some level of independent administrative capacity, notably the rise of relatively permanent and separate institutions that are able to act relatively independently from preexisting political institutions. In his analysis of institutionalization in the context of political development, Huntington (1968) argued that autonomy was a first requirement of successful state development. An independent European administrative system must possess some capacity of its own (Zürn, 2012, 731). Envisaged already by Saint-Simon in 1814 (1964, 35-8), one necessary factor in building common administrative systems - even common political order - is the establishment of common institutions, including a permanent congress, independent of national governments, serving the common interest. This book shows how the growth of administrative capacities not only within the Commission but also in institutions surrounding it may contribute to strengthening its independent capacities. Independent administrative capacities will subsequently enable the independent development and implementation of public policy at or from a 'European' level. This book shows how the rise of independent administrative capacities in the International Atomic Energy Agency (IAEA) has been conducive to de facto independence of this international administration, even though it works within a policy field which is highly delicate - nuclear power. Finally, the book demonstrates that the rise of accountability capacities which may enable the EU to curb the executive power of the Commission. The European Parliament, supported by the European Ombudsman, has established emergent accountability procedures that first enable it to control administrative malpractice in the Commission, but increasingly also enable it to survey malpractice within member-state government institutions, thus establishing an emergent multilevel accountability structure. Consequently, political order formation involves continuous tensions between administrative dependence and independence within and between administrative systems.

\section{Integration}

International institutions center attention on varying degrees of inter- and intra-organizational coordination of administrative capacities and the extent to which this is challenged by parallel fragmentation, 'silo-ization' and sub-culturalization of the administrative services. The question also 
remains of how competing patterns of administrative integration and disintegration may coexist within the administrations - for example by being embedded and layered within different administrative sub-units. Empirically it is often observed that the rise of common political order does not result in the institutionalization of coherent administrative capacities. Instead, different components of administrative centers do usually overlap, counteract and layer, and sometimes are out of sync rather than integrated, coordinated and 'ordered' (Orren and Skowronek, 2004). Supplementing the vertical specialization of administrative systems, the internal integration of administrative systems is increasingly documented within national governments - notably reasserting centers of executive government (Peters, 2004; Poguntke and Webb, 2005). Similarly, one strand of contemporary research suggests that the European Commission has become increasingly integrated - within the Commission administration itself as well as between the Commission administration and the College of Commissioners and their respective cabinets (Wille, 2012). The history of the Commission documents different periods of internal integration. Best known, perhaps, is the Delors Commission (1985-94), characterized by presidential steering and a relative disregard of administrative routines (Christiansen, 2008, 63; Kassim, 2006) and their legacy. However, previous studies also reveal a pattern of administrative silo-ization at the heart of policy departments in the Commission (Trondal, 2012). At the same time we see organizational capacities emerging around the Commission President, partly by reforming the Secretariat-General (SG) into an administrative service center at the disposal for the president (Kassim et al., 2013). Thus, political order formation involves a continuous balancing act between integration and disintegration of administrative systems.

\section{Influence}

Common order also requires that new political institutions are relatively able to influence and challenge decision-making processes within other political institutions. The independence and integration of administrative capacities within emergent political orders may not only have implications for how they formulate and enact public policy. The rise of independent and integrated administrative capacities within such orders may also increase their ability to influence and challenge other existing political institutions. EU-level administrations - such as the Commission - may for example develop capacities to influence governance processes within so-called EU agencies. Moreover, the Commission may develop capacities to interfere in the activities of agencies at the national level of government - making them in practice partly European and partly national. Moreover, the 
Commission may also perhaps influence agencies within other international organizations thus reaching into global administrative architectures.

From an organization theory point of view, the question of how administrations are organized is thought to affect how they evolve and how they work (Egeberg et al., 2016). The horizontal specialization of administrations may, for example, affect how they influence and challenge other institutions and also what parts of other institutions are indeed influenced. For example, the sector-specialization of the Commission's services may affect how the Commission influences administrative subunits. This may be reflected in the development of direct linkages between Commissioners and 'their' EU agencies, as well as the development of relatively tight ties between Commission Directorate-Generals (DGs) and domestic agencies that work within similar policy fields. Moreover, horizontal networks of both regulators (Yesilkagit, 2011) and domestic agencies (Egeberg and Trondal, 2009) may be influenced by the Commission and offer supplies of relevant administrative capacities.

\section{SO WHAT?}

The above analytical dimensions serve not only to capture central aspects of the rise of common political order in Europe, but also to accentuate what makes the public administration approach different from its major 'rival', the multilevel governance (MLG) approach. This section suggests that the MLG and MLA approaches diverge with respect to (i) unit of analysis, (ii) organizational differentation, and (iii) sources of contingency of governance (Table 1.1). Our point here is not to recap the MLG approach (Bache and Flinders, 2004; Hooghe and Marks, 2004; Piattoni, 2010), but to suggest how a public administration approach may pay attention to the administrative dimension of political order formation and thus complements and helps systematize a more encompassing theory of political order formation. In short, a public administration approach (MLA) highlights analytical dimensions of political order formation largely left untouched.

First, the unit of analysis differs in MLG and MLA approaches. The MLG approach has both historically and contemporarily applied (subnational) regions as their favorite unit of analysis (Marks et al., 1996b; Marks et al., 2008, 113; Piattoni, 2010). Focus has been on the relative autonomy of regions and how this autonomy supplies regions with a capacity to bypass state governments in their interaction with the Brussels apparatus. One conclusion is that the separation of domestic and international politics and thus domestic and foreign affairs administrations - is ambiguous due 
Table 1.1 Key variations between the MLG and MLA approach

\begin{tabular}{|c|c|c|}
\hline & $M L G$ & $M L A$ \\
\hline Unit of analysis & $\begin{array}{l}\text { Political arenas } \\
\text { (e.g. subnational } \\
\text { authorities, 'regions') }\end{array}$ & $\begin{array}{l}\text { Administrative institutions } \\
\text { (Public sector organizations, } \\
\text { and their sub-units) }\end{array}$ \\
\hline $\begin{array}{l}\text { Organizational } \\
\text { differentiation }\end{array}$ & $\begin{array}{l}\text { No differentiation } \\
\text { ('regions' treated as } \\
\text { black boxes) }\end{array}$ & $\begin{array}{l}\text { High degree of differentiation } \\
\text { (administrative systems } \\
\text { consisting of horizontally } \\
\text { and vertically specialized } \\
\text { sub-units) }\end{array}$ \\
\hline $\begin{array}{l}\text { Sources of contingency } \\
\text { of (administrative) } \\
\text { governance }\end{array}$ & $\begin{array}{l}\text { The supply of regional } \\
\text { authority }\end{array}$ & $\begin{array}{l}\text { The supply of administrative } \\
\text { capacities at different levels of } \\
\text { government }\end{array}$ \\
\hline
\end{tabular}

Source: Trondal $(2015,489)$.

to the interconnectedness of political authority across levels of governance (Hooghe and Marks, 2001, 4). In contrast, the MLA approach suggests that research focus should shift from regions towards the administrative interior of government institutions at different levels of government, principally towards administrative sub-units at each level, and how these mutually relate. To illustrate, the MLA approach directs attention towards the behavior and role perceptions of unelected office holders (Trondal et al., 2010), the autonomy and interaction of sub-units at each administrative level (Ege and Bauer, 2013; Egeberg, 2006; Trondal and Peters, 2013), the 'in-house' socialization processes of staff (Beyers, 2010), and so on. Focus is thus not primarily on government apparatuses as arenas, but rather on government apparatuses as normative structures that mobilize bias (Schattschneider, 1975) and that contribute to a systematic patterning of behavioral patterns among office holders (Simon, 1957). Consequently, the way administrative sub-units are formally organized at all levels of government is assumed to bias the roles, beliefs, identities and behavior evoked by the staff involved, and ultimately the multilevel administrative governance processes being processed. Such organizational characteristics might include organizational capacity, organizational specialization (horizontal/vertical), organizational affiliation (primary/secondary), organizational coupling (tight/loose), and so on.

Second, assumptions on the coherence of units of analysis vary between MLG and MLA approaches. Although the MLG approach successfully challenged the coherent nature of states (Piattoni, 2010, 2), at the same time it largely treated its unit of analysis - regions - as coherent units 
of analysis. Importantly, the dimensions applied to measure regional authority in the MLG approach did not encompass the organizational architecture of regions (Marks et al., 2008, 115 - table 1). For example, the nine dimensions applied by Marks et al. (2008) to measure local authority aimed to gauge relationships between regions (as coherent black boxes) and national governments. None of these dimensions, however, suggested how the administrative interior of regions makes a difference in this regard. This lack of interest in the administrative inland of regions is a direct consequence of the fact that the MLG approach is basically interested in 'the allocation of authority across general purpose jurisdictions' and not the internal administrative architecture of regions as items for analysis (Marks et al., 2008, 111).

This lack of attention to the organizational dimensions of political order formation in the MLG approach is paralleled in international organization (IO) studies. Recent research on governance in IOs pays only scant attention to the bureaucracies of these organizations (Hawkins et al., 2006; Karns and Mingst, 2004, but see Biermann and Siebenhühner, 2009; Bauer and Ege, 2014). One explanation for this lack of scholarly attention to the administrative dimension is partly the gulf that exists between IO literature and public administration literature. One clear example of this gulf is the book by Acharya and Johnston (2007) that makes a comparative analysis of IOs without mentioning their administrative systems. Rationalist accounts of IOs - the realist, neo-realist and liberalist variants - largely treat international administrations as epiphenomena of the interaction of states. Studies of IOs have been preoccupied with studying the more visible interplay of states rather than the back-stage activities of the secretariats (Rochester, 1986). One notable exception is the growing volume of studies of the Commission and to some extent reports on the UN Secretariat (Chesterman, 2007; Egeberg, 2006). Researching the everyday decision making of international bureaucracies has been of less interest than studying the voting behavior of states in general assemblies (Hix, 2002), analyzing the great leaders of international bureaucracies, such as the UN General Secretary (Chesterman, 2007; Cox, 1969, 202; Rochester, 1986), and studying reforms of IOs (Bauer and Knill, 2007). Similarly, regime analysis tends to look at international administrations as intervening variables that 'somehow affect regime outcomes', thus not treating international administrations as institutions in their own right (M.W. Bauer, 2006, 26; Reinalda, 2013; Underdal, 2008). The seminal work of Cox and Jacobson $(1973,428)$ reflects this lack of administrative focus, concluding that 'international organizations facilitate the orderly management of intergovernmental relations without significantly changing the structure of power that governs these relations'. Discovering that 
international administrations can have identities, resources, authority, and interests of their own was, of course, an important development (Barnett and Finnemore, 2004). However, seen from a public administration point of view, these observations are less surprising (Ege and Bauer, 2013). The MLA approach treats their units of analysis as internally differentiated. It is assumed that different degrees and types of organizational differentiation both at the national and the EU level - may have systematic implications on multilevel administrative governance processes. Viewing political order as specialized structures implies institutional differentiation and separation of powers (Olsen, 2016, 8).

Finally, MLG and MLA approaches diverge on core assumptions on the contingency of governance processes. In short, their basic ontology differs. The MLG approach has been successful in measuring regional authority, and thus in accounting for local conditions of multilevel processes (Marks et al., 2008). It is assumed that multilevel processes are primarily fostered by different degrees and types of regional autonomy, although contemporary MLG research is also increasingly interested in assessing IO authority (Hooghe and Marks, 2015). Essentially, the MLG approach is theoretically actor-centered (Marks et al., 1996a, 348). To the extent that institutional variables enter the equation, they are treated as aggregative items (Marks et al., 1996b, 170) and thus compatible with a thin "exchange based' conception of institutions. In such an account, 'politics can be seen as aggregating individual preferences into collective action by procedures of rational bargaining, negotiation, coalition formation, and exchange' (March and Olsen, 1995, 7). Institutional variables are merely treated as intervening variables that constrain purposeful action. Nowhere does the MLG approach 'unpack' institutions as independent variables.

By contrast, the MLA approach assumes institutions to be independent variables. One crucial causal mechanism in the MLA approach is the supply of administrative capacities at each level of government. It is suggested that the supply of organizational capacities at the sub-unit level may have certain implications for how organizations and humans act. Whereas the MLG approach perhaps can be conceived as a theory of political mobilization (Piattoni, 2010), the MLA approach is a theory of political organization. It is assumed that organizational capacity building provides government institutions with leverage to act independently, to enable them some degree of internal integration, and to make them influential towards external institutions. The MLA approach departs from the assumption that norms, rules and routines embedded in institutions mobilize biases in public policy because these factors offer cognitive and normative shortcuts and categories that simplify and guide decision makers' search for satisficing and appropriate solutions (Cyert and March, 1963; March and Olsen, 
1989; Schattschneider, 1975; Simon, 1957). Consequently, the decisionmaking behavior of actors is likely to reflect their primary organizational embedment into government institutions and their sub-units.

Two empirical predictions follow from this assumption: First, the supply of independent administrative capacities is necessary for government institutions to act and to affect how other institutions act. In short, the rise of political order is organizationally contingent and systematically supplied and biased by administrative rules and routines. For example, the supply of administrative capacities in the Commission is expected to increase the likelihood that signals from the Commission will be ascribed importance by officials in other EU institutions and in domestic agencies. In effect, patterns of multilevel administrative governance between sub-units are assumed to be supplied by the variety of administrative capacities of the Commission. Second, the behavior, role and identity perceptions evoked by government officials are expected to be primarily directed towards those administrative sub-units that are the primary supplier of relevant decision premises. It is assumed that multilevel administrative governance is facilitated by the organizational capacities of government sub-units at both levels of government. One empirical implication is administrative integration along sectoral lines, for example between Commission departments and agency sub-units, or between sub-units of various regions and municipalities. The MLA approach may offer attention to the administrative dimension of emergent orders, and thereby, in sum, is an important element in a broader theory of political order formation.

\section{OUTLINE OF THE BOOK}

\section{Part I Political Order at the International Level}

Chapter 2 offers a state-of-the-art review of existing research on international administration and a research agenda for this field of scholarship. As an area of research, specifying crucial conditions under which international public administration (IPA) may enjoy independence from member-state governments has become an increasingly vibrant research area. This chapter discusses three yet unresolved research tasks: (i) systematically comparing IPAs by offering large-N data across cases; (ii) taking organization seriously by identifying how the organizational architectures of IPAs affect decisionmaking processes and subsequently the pursuit of public policy making; and finally (iii) examining the varied consequences of the autonomization of IPAs, notably for member-state public sector governance and for the integration of transnational regulatory regimes. 
Chapter 3 identifies how IPAs in practice may operate relatively independently from member-state governments, even when embedded in de jure intergovernmental international organizations, and even when operating in policy areas subject to tight member-state control. The case study presented is the International Atomic Energy Agency (IAEA). Studying bureaucratic independence at the actor level, this chapter demonstrates that IAEA officials enjoy behavioral independence and that this actor-level independence is considerably contingent on how the IAEA secretariat is internally organized. This pattern is accounted for by applying an organization theory approach. The study thus illustrates secretary activism within formally intergovernmental organizations, but also the limitations and conditions thereof.

Chapter 4 examines the rise of independent supranational administration with the case of the EU administration. Throughout its history the EU system has faced shifting, hostile and uncertain environments, and responded by erecting turbulent organizational solutions of various kinds. This chapter discusses some key features of this development and the ensuing consequences for the independence of the Commission administration. This also opens an opportunity to rethink governance in nascent administrative systems, which requires research focus towards the supply of administrative capacities beyond the executive center - notably EU agencies and domestic agencies. The turbulence of the system is discussed by analyzing the institutional independence and integration of its parts.

Chapter 5 discusses how the power of IPAs may be curbed by independent accountability institutions. The chapter discusses the role of the European Parliament as the core accountability mechanism of the EU. Moreover, one relatively unstudied component in this regard is the development of the European Ombudsman as a supplementary accountability mechanism. At the national level, nearly all EU member states have introduced an ombudsman. At the EU level, there has been an ombudsman institution since 1995. This chapter sheds light on the strategies with which the European Parliament and the European Ombudsman prove able to build capacity and adjust institutionally to the changing politico-administrative context. Drawing on an analysis of documents and a secondary analysis of existing empirical data, this chapter examines the institutional development of the European Parliament and the European Ombudsman over the past two decades.

\section{Part II Political Order at the Macro-regional Level}

Chapter 6 offers a state-of-the-art review of research on political order formation at the macro-regional level in the EU. The chapter brings 
together different strands of literature, in particular from political science, spatial planning and geography. Drawing on previous examples of subregional cooperation, such as Baltic Sea regional cooperation, EU macroregional strategies have recently been introduced as a new instrument in the EU's territorial cooperation and cohesion policy repertoire. To date, four macro-regional strategies have been developed (Baltic Sea Region, 2009, Danube Region, 2011, Adriatic-Ionian Region, 2014 and the Alpine Region Strategy, 2015). By establishing comprehensive frameworks for cross-sectoral policy coordination (e.g. transport infrastructure and environmental protection) and hence proposing a new form of territorially bound common political order, these strategies aim to encourage EU member/partner countries in macro-regional territories to contribute to active territorial cooperation. Macro-regions have generated scholarly interest across a number of disciplines, including geography, regional and spatial planning, political science and public administration. The emergence of macro-regional strategies has led to new questions and academic debates on issues such as their impacts on existing practices of territorial cooperation and whether they challenge or complement previously established formats of (sub-)regional cooperation. Drawing on a review of existing literature, this contribution seeks to take stock of existing research on the subject, discuss the conceptual starting points, and chart possible directions for future research. The chapter concludes that the conceptual debates in political and spatial sciences exhibit a number of overlaps that might be fruitfully explored in the future.

Chapter 7 explores the EU Strategy for the Baltic Sea Region (EUSBSR) and the EU Strategy for the Danube Region (EUSDR), the EU's most established macro-regional strategies (in operation since 2009 and 2011 respectively), in more depth. The macro-regional strategies of the EU - new elements of EU Cohesion Policy and European Territorial Cooperation have emerged at a critical juncture of the European common political order. In a nutshell, these strategies aim to foster functional and transnational 'macro-regions' involving the EU and its member states, as well as partner countries and other stakeholders of the loosely defined 'macro-region' such as that of the Baltic Sea Region. Although EU macro-regional strategies have hitherto neither been equipped with substantial financial resources nor been equipped with proper institutions or specific legislation, they have triggered the establishment of a governance architecture which includes several issue-specific trans-governmental networks. Combining theoretical assumptions drawn from the experimentalist governance and multilevel governance (MLG) approaches, this contribution first explores the dynamics of the macro-regional governance architecture, second assesses the effects in terms of the political mobilization and interplay between 
international, intergovernmental and non-governmental actors, and third provides a comparative discussion of these most established macroregional strategies. It finds that EU macro-regional strategies represent an innovative combination of bottom-up and top-down approaches of EU governance, and also combine features of experimentalist governance with more conventional forms of governance.

Chapter 8 seeks to unpack the internal fabric of the EU macro-regional governance architecture by zooming into the system of Priority Area Coordinators (PACs) and Horizontal Action Leaders (HALs), analyzed against the backdrop of the EUSBSR. The primary task of PACs and HALs is to involve relevant stakeholders across different policy sectors and levels of governance in the implementation of a macro-regional strategy. This contribution unpacks the internal dynamic of the core of the EUSBSR governance architecture by mapping the role, main tasks, and patterns of inter-organizational contacts as well as the self-perception of PACs and HALs in the EUSBSR. Building on data provided by a survey as well as a number of interviews conducted with PACs and HALs, the article explores the first generation of PACs and HALs. One of the key findings suggests that, first, PACs and HALs constitute a new trans-governmental policy network between participating countries and, second, they help the European Commission extend its reach into the bureaucracies of participating countries, EU members and partner states alike.

\section{Part III Political Order at the Local Level}

Chapter 9 offers a state-of-the-art review of research on political order formation at the local level. Several theoretical frameworks have been proposed to analyze cooperative arrangements between and within local and regional authorities. The most prominent currently is probably the network approach, often lumped under the heading of governance. Another is the Institutional Collective Action framework. This chapter applies a third theoretical strain: the inter-organizational relations approach. Here the focus is set on relations between formal and autonomous, yet interdependent, organizations 'that pursue a common goal and generate a collective output' (Raab et al., 2015). The inter-organizational relations framework clearly overlaps both the network and the Institutional Collective Action approach, but its explicitly organizational element allows for a narrower focus on certain elements. First, it defines coordination as a behavioral process where actors join resources and adapt actions to each other. The focus is thus set on interactions and relations between actors, and the types, forms and contents of these relations. Interactions and relations - or, actual behavior - can furthermore be treated as both 
dependent variables (affected by something) and independent variables (affecting an output or outcome). Second, such an approach concentrates on how this interaction is organized, including both the formal and the informal elements. Using basic organization theory the focus is set on organizational dimensions like formal structure, trust, power and culture. Organization may in turn be treated as both an independent variable (affecting behavior) and a dependent variable (affected and changed by something). Third, the inter-organizational relations approach acknowledges explicitly the fact that the actors that are supposed to coordinate activities themselves are organizations. Thus it becomes important to understand how characteristics of the organizational structures of the actors affect the coordination between the actors.

Chapter 10 examines if the rise of new politico-administrative institutions may challenge and influence pre-existing institutions. During the 1980s, one could observe an emerging trend of inter-municipal cooperation all over Europe. To compensate for lack of size, municipalities erected cooperative arrangements, combining the resources of two or more municipalities to provide a service or solve a problem. This trend has continued, arguably with increasing strength. This chapter first defines different forms of inter-municipal cooperation and links them to their autonomy from their respective participants. Second, the chapter empirically analyzes a critical case: political cooperation between Norwegian municipalities organized in a 'new' and formalized organizational entity. The chapter ends with a discussion of findings. One observation made is that regional councils in Norway are only to a minor degree perceived as being democratic threats. But, this general picture must arguably be nuanced. The main reason for this is that it is often assumed, implicitly, that municipalities engaging in inter-municipal cooperation are similar.

Chapter 11 analyzes new joint ventures at the local level. There is a call for studies on how cooperation between local governments affects costs. Is the rise of new institutional formats - which in some cases implies the rise of more sizable political orders - costly or efficient? Do joint ventures produce economies of scale? The main ambition of this chapter is to contribute to fill this void by examining (i) whether inter-municipal cooperation leads to more cost-efficient service delivery than producing services municipally and (ii) whether different forms of cooperation affect cost-efficiency differently. Conceptually these questions tap into the puzzle of whether cooperation promotes scale economies or whether transaction costs exceed potential scale advantages. The author seeks to answer this by analyzing how cooperation and non-cooperation within Norwegian emergency services affect operating costs. The chapter shows that cooperation, whether it is organized by market principles or joint organizations, is 
a more costly organizational form than the traditional local hierarchy. How much more costly it is, however, depends on the number of actors involved. This implies that costs related to cooperation exceed potential cost savings provided by economies of scale, and that joint service provision therefore does not solve efficiency problems linked to small-scale entities.

Finally, Chapter 12 analyzes what causes the breakdown of newly established politico-administrative orders. Following increased cooperation across territorial and administrative borders, research on successful interorganizational relations - such as networks, joint ventures, alliances, and partnerships - has grown considerably. Still, knowledge about what factors and events lead to their breakdown is scarce. In fact, there is little knowledge on how to conceptualize breakdown; how to distinguish it from radical change or even symbolic changes in appearance. The chapter offers a conceptualization of the breakdown of cooperation, and discusses how to measure it empirically. Moreover, this chapter outlines explanatory variables of breakdown in three groups: structural, contextual and process based. Finally, the chapter conducts a comparative empirical evaluation of four similar inter-municipal cooperative arrangements in Norway (called regional councils) - two of which experienced a breakdown and two which are still fully functional. Regional councils are voluntary arrangements, products of bottom-up processes, and thus not mandated by central government. Furthermore, they are multifunctional, involved in spatial and social planning, coordination of regional initiatives regarding common regional resources (water, transport, culture etc.), and sometimes initiating and overseeing inter-municipal service delivery with the aim of optimizing regional potential and minimizing risk and costs.

\section{CONCLUSIONS}

This book suggests a conceptual frame through which administrative dimensions of political order formation may be understood. The ambition of the book is first to offer a conceptual frame that takes the 'administrative dimensions' seriously, thereby also suggesting that previous accounts of polity formation have left this dimension largely to the side. Second, this book suggests how the public administration (MLA) approach adds value to such an analysis which one of its conceptual rivals - the multilevel governance (MLG) approach - does not. Finally, the book offers some empirical illustrations of the public administration approach in the contemporary European administrative system. In sum, the book suggests that the public administration approach is an important element in a broader theory of political order formation. The MLA approach 
may pay attention to the administrative dimension, and its added value is the conceptualization of administrative structures, values and interaction across levels of government - it is therefore a (partial) theory of political organization.

The theoretical interest in the administrative dimension of the EU polity is related to the challenge that the emerging EU administrative system poses for the discipline of public administration which has been largely locked in national laboratories. Theoretical lessons from the social sciences are arguably affected by the empirical laboratories available to scholars. The domain of public administration may arguably gain theoretical advances by challenging methodological nationalism. Moreover, despite successful advances in conceptualizing the EU administrative system, this volume argues that public administration as a sub-discipline has paid scant attention to how the rise of administration and administrative systems is essential to the rise of political order. The administrative dimension of political order formation is captured in this volume along three analytical dimensions: institutional independence, integration and influence. These dimensions serve first to capture central aspects of the integration of public administration in Europe, and second to accentuate what makes the public administration approach valuable.

Future studies applying the MLA approach could be potentially manifold. The MLA is of relevance for studying how federal-type systems - such as the EU - integrate, and particularly the organizational dimension of such processes. This approach is also of relevance for studying the settlement of emergent organizations and organized systems. Organizations and organized systems are temporary settlements of rules and procedures, demography, locations, beliefs and norms. The MLA approach is particularly helpful in conceptualizing the institutionalization of emergent systems that involves multiple tiers of authoritative decision centers. Finally, we would also emphasize the attractiveness of studying the sustainability of political orders. One way to do this would be to study how they operate under stress and turbulence. The sustainability and resilience of political order may be taken for granted during periods of stability. During periods of turbulence, these items might be subject to testing. Turbulent times - such as those typically associated with financial stress - are marked by the lack of 'order, rationality, control and predictability' (Cohen et al., 2012, 7). Turbulence is characterized by long-term unruliness and tensions within environments and organizations that might go unnoticed by practitioners and observers. As seen by the recent Euro-zone crisis in Europe, the Euro was marked by some kind of unsettledness right from the launch of the new Euro area, but the sudden crisis that hit Greece - and subsequently other EU member states - unveiled the latent turbulent nature of the arrangement. 
During turbulence, decision makers face choices that need to be made under circumstances of unfamiliar degrees of uncertainty (Tamuz and Lewis, 2008, 158). Turbulent times can reveal the fragility of institutions and produce surprising cascading dynamics that test the sustainability of political orders. We suggest that turbulent times also represent an underappreciated opportunity to examine the resilience of organizations and organized systems. Less attended to by contemporary scholarship, unsettled systems of governance offer ample opportunity for scholarly reflection, taking stock, and suggesting new ways forward.

\section{REFERENCES}

Acharya, A. and A.I. Johnston (eds) (2007) Crafting Cooperation. Cambridge: Cambridge University Press.

Amoretti, F. and F. Musella (2011) 'Towards the European administrative space: the role of e-government policy', European Political Science Review, 3 (1), 35-52.

Ansell, C. and G. Di Palma (eds) (2004) Restructuring Territoriality. Cambridge: Cambridge University Press.

Ansell, C., J. Trondal and M. Øgård (eds) (2017) Governance in Turbulent Times. Oxford: Oxford University Press.

Arellano-Gault, D., D. Demortain, C. Rouillard and J.-C. Thoenig (2013) 'Bringing public organizations and organizing back in', Organization Studies, 34 (2), 145-67.

Bache, I. and M. Flinders (eds) (2004) Multilevel Governance. Oxford: Oxford University Press.

Barnett, M. and M. Finnemore (2004) Rules for the World. Ithaca, NY: Cornell University Press.

Bartolini, S. (2005) Re-structuring Europe. Oxford: Oxford University Press.

Bauer, M.W. (2006) 'Co-managing programme implementation: conceptualizing the European Commission's role in policy execution', Journal of European Public Policy, 13 (5), 717-35.

Bauer, M.W. and S. Becker (2014) 'The unexpected winner of the crisis: the European Commission's strengthened role in economic governance', Journal of European Integration, 36 (3), 213-29.

Bauer, M.W. and J. Ege (2014) 'The autonomy of international bureaucracies', in S. Kim, S. Ashley and H. Lambright (eds) Public Administration in the Context of Global Governance. Cheltenham, UK and Northampton, MA, USA: Edward Elgar.

Bauer, M.W. and C. Knill (eds) (2007) Management Reforms in International Organizations. Baden-Baden: Nomos.

Bauer, M.W. and J. Trondal (eds) (2015a) The Palgrave Handbook on the European Administrative System. Houndmills, Basingstoke, UK: Palgrave Macmillan.

Bauer, M.W. and J. Trondal (2015b) 'The administrative system of the European Union', in M.W. Bauer and J. Trondal (eds) The Palgrave Handbook of the European Administrative System. Houndmills, Basingstoke, UK: Palgrave Macmillan. 
Bauer, S. (2006) 'Does bureaucracy really matter? The authority of intergovernmental treaty secretariats in global environmental politics', Global Environmental Politics, 6, 23-49.

Benz, A. (2012) 'The European Union as a loosely coupled multilevel system', in H. Enderlein, S. Wälti and M. Zürn (eds) Handbook on Multilevel Governance. Cheltenham, UK and Northampton, MA, USA: Edward Elgar.

Benz, A. (2015) 'European public administration as a multilevel system administration: a conceptual framework', in M.W. Bauer and J. Trondal (eds) The Palgrave Handbook on the European Administrative System. Houndmills, Basingstoke, UK: Palgrave Macmillan.

Berlin, D., S. Pag and C. Bourtembourg (eds) (1987) The European Administration. Maastricht: EIPA.

Beyers, J. (2010) 'Conceptual and methodological challenges in the study of European socialization', Journal of European Public Policy, 17, 909-20.

Bickerton, C.J. (2012) European Integration. Oxford: Oxford University Press.

Bickerton, C.J., D. Hodson and U. Puetter (2015) The New Intergovernmentalism. Oxford: Oxford University Press.

Bulmer, S. (2008) 'Building a multi-level polity in Europe', in U. Sverdrup and J. Trondal (eds) The Organizational Dimension of Politics. Bergen: Fagbokforlaget.

Cassese, S. (1987) 'Divided powers: European administration and national bureaucracies', in D. Berlin, S. Pag and C. Bourtembourg (eds) The European Administration. Maastricht: EIPA.

Checkel, J.T. (2005) 'International institutions and socialization in Europe', International Organization, 59, 801-26.

Chesterman, S. (ed.) (2007) Secretary or General? Cambridge: Cambridge University Press.

Chiti, M.P. (2004) 'Forms of European administrative action', Law and Contemporary Problems, 68, 37-57.

Christiansen, T. (2008) The Institutional Politics of the European Union. PhD Thesis. University of Maastricht.

Christensen, T. and P. Lægreid (eds) (2007) Transcending New Public Management: The Transformation of Public Sector Reforms. Aldershot, UK: Ashgate.

Christensen, T. and P. Lægreid (2011) 'Beyond NPM? Some development features', in T. Christensen and P. Lægreid (eds) The Ashgate Research Companion to New Public Management. Aldershot, UK: Ashgate.

Cohen, M.D., J.G. March and J.P. Olsen (2012) “"A Garbage Can Model” at forty: a solution that still attracts problems', in A. Lomi and J.R. Harrison (eds) The Garbage Can Model of Organizational Choice: Looking Forward at Forty. Bingley, UK: Emerald.

Cox, R.W. (1969) 'The executive head: an essay on leadership in international organization', International Organization, 23, 205-30.

Cox, R.W. and H.K. Jacobson (1973) The Anatomy of Influence. New Haven, CT: Yale University Press.

Curtin, D. and M. Egeberg (2008) 'Tradition and innovation: Europe's accumulated executive order', West European Politics, 31, 639-61.

Cyert, R.M. and J.G. March (1963) A Behavioral Theory of the Firm. Englewood Cliffs, NJ: Prentice-Hall.

Dahlström, C., V. Lapuente and J. Teorell (2012) 'Public administration around the work', in S. Holmberg and B. Rothstein (eds) Good Government. Cheltenham, UK and Northampton, MA, USA: Edward Elgar. 
Danielsen, O.A. and K. Yesilkagit (2014) 'The effects of European regulatory networks on the bureaucratic autonomy of national regulatory authorities', Public Organization Review, 14, 353-71.

Ege, J. and M.W. Bauer (2013) 'International bureaucracy from a public administration and international relations perspective', in B. Reinalda (ed.) Routledge Handbook of International Organization. London: Routledge.

Egeberg, M. (ed.) (2006) Multilevel Union Administration. Houndmills, Basingstoke, UK: Palgrave Macmillan.

Egeberg, M. (2010) 'L'administration de l'Union Europeenne: Niveaux Multiples et Construction d'un Centre', Revue Francaise d'Administration Publique, 133, 17-26.

Egeberg, M., Å. Gornitzka and J. Trondal (2016) 'Organization theory', in C. Ansell and J. Torfing (eds) Handbook on Theories of Governance. Cheltenham, UK and Northampton, MA, USA: Edward Elgar.

Egeberg, M. and J. Trondal (2009) 'National agencies in the European administrative space: government driven, Commission driven, or networked?', Public Administration, 87, 779-90.

Eising, R. and B. Kohler-Koch (1999) 'Introduction: network governance in the European Union', in B. Kohler-Koch and R. Eising (eds) The Transformation of Governance in the European Union. London: Routledge.

Ellinas, A.A. and E. Suleiman (2012) The European Commission and Bureaucratic Autonomy. Cambridge: Cambridge University Press.

Elster, J. (2007) Explaining Social Behavior. Cambridge: Cambridge University Press.

Emery, Y. and D. Giauque (2014) 'The hybrid universe of public administration in the 21 st century', International Review of Administrative Sciences, 80 (1), 23-32.

Eulau, H. (1977) 'The place of policy analysis in political science: five perspectives', American Journal of Political Science, 21, 419-23.

Franchini, C. (2004) 'European principles governing national administrative proceedings', Law and Contemporary Problems, 68 (1), 183-96.

Fukuyama, F. (2014) Political Order and Political Decay. New York: Farrar, Straus and Giroux.

Fukuyama, F. (2016), 'Macro theory and the study of political development', Scandinavian Political Studies, 39 (3), 207-25.

Gänzle, S. and K. Kern (eds) (2016) A 'Macro-regional' Europe in the Making. Theoretical Approaches and Empirical Evidence. Houndsmill, Basingstoke, UK: Palgrave Macmillan.

Gaus, J.M. (1950) 'Trends in the theory of public administration', Public Administration Review, 10 (3), 161-8.

Gulick, L. (1937) 'Notes on the theory of organizations. With special references to government in the United States', in L. Gulick and L. Urwick (eds) Papers on the Science of Administration. New York: Institute of Public Administration, Columbia University.

Haas, E.B. (1958) The Uniting of Europe. Notre Dame, IN: Notre Dame Press.

Hawkins, D.G., D.A. Lake, D.L. Nielson and M.J. Tierney (eds) (2006) Delegation and Agency in International Organizations. Cambridge: Cambridge University Press.

Heidbreder, E.G (2011) 'Structuring the European administrative space: policy instruments of multilevel administration', Journal of European Public Policy, 18 (5), 709-27. 
Heidbreder, E.G. (2015) 'Horizontal capacity pooling: direct, decentralized, joint policy execution', in M.W. Bauer and J. Trondal (eds) The Palgrave Handbook on the European Administrative System. Houndmills, Basingstoke, UK: Palgrave Macmillan.

Hix, S. (2002) 'Parliamentary behavior with two principals: preferences, parties, and voting in the European Parliament', American Journal of Political Science, 46, 688-98.

Hofmann, H.C.H. and A.H. Turk (eds) (2006) EU Administrative Governance. Cheltenham, UK and Northampton, MA, USA: Edward Elgar.

Hooghe, L. and G. Marks (2001) Multilevel Governance and European Integration. New York: Rowman \& Littlefield Publishers.

Hooghe, L. and G. Marks (2004) 'Does identity or economic rationality drive public opinion on European integration?', Political Science and Politics, 37, 415-20.

Hooghe, L. and G. Marks (2015) 'Delegation and pooling in international organizations', Review of International Organizations, 10 (3), 305-28.

Huntington, S.P. (1968) Political Order in Changing Societies. New Haven, CT: Yale University Press.

Karns, M.P. and K.A. Mingst (2004) International Organizations. London: Lynne Rienner Publishers.

Kassim, H. (2006) 'The secretariat general of the European Commission', in D. Spence (ed.) The European Commission. London: John Harper Publishing.

Kassim, H., B.G. Peters and V. Wright (eds) (2000) The National Co-ordination of EU Policy: The Domestic Level. Oxford: Oxford University Press.

Kassim, H., J. Peterson, M.W. Bauer, S. Connolly, R. Dehousse, L. Hooghe and A. Thompson (2013) The European Commission of the Twenty-First Century. Oxford: Oxford University Press.

Keohane, R.O., S. Macedo and A. Moravcsik (2009) 'Democracy-enhancing multilateralism', International Organization, 63, 2009

Knill, C. (2001) The Europeanisation of National Administrations. Cambridge: Cambridge University Press.

Kristof, N. (2016) “"Big government” looks great from here', International New York Times, 18 March.

March, J.G. (1999) 'A learning perspective on the network dynamics of institutional integration', in M. Egeberg and P. Lægreid (eds) Organizing Political Institutions. Essays for Johan P. Olsen. Oslo: Scandinavian University Press.

March, J.G. (2009) 'Public administration, organizations, and democracy', in P.G. Roness and H. Sætren (eds) Change and Continuity in Public Sector Organizations: Essays in Honour of Per Lagreid. Bergen: Fagbokforlaget.

March, J.G. and J.P. Olsen (1989) Rediscovering Institutions. New York. The Free Press.

March, J.G. and J.P. Olsen (1995) Democratic Governance. New York: The Free Press.

Marks, G. (1993) 'Structural policy and multilevel governance in the EC', in A.W. Cafruny and G.G. Rosenthal (eds) The State of the European Community: The Maastricht Debates and Beyond. Boulder, CO: Lynne Rienner Publishers.

Marks, G., L. Hooghe and K. Blank (1996a) 'European integration from the 1980s: state-centric v. multilevel governance', Journal of Common Market Studies, 34 (3), 341-78. 
Marks, G., L. Hooghe and A.H. Schekel (2008) 'Measuring regional authority', Regional and Federal Studies, 18, 111-21.

Marks, G., F. Nielsen and L. Ray (1996b) 'Competencies, cracks, and conflicts: regional mobilization in the European Union', Comparative Political Studies, 29 (2), 164-92.

Martens, M. (2010) Organized Administrative Integration. ARENA Report 2.

Meyer-Sahling, J.-H. and K. Yesilkagit (2011) 'Differential legacy effects: three propositions on the impact of administrative traditions on public management reform in Europe east and west', Journal of European Public Policy, 18, 311-22.

Moravcsik, A. (1998) The Choice for Europe. Ithaca, NY: Cornell University Press.

Niemann, A. (2006) Explaining Decisions in the European Union. Cambridge: Cambridge University Press.

Niemann, A. and P.C. Schmitter (2009) 'Neofunctionalism', in A. Wiener and T. Diez (eds) European Integration Theory. Oxford: Oxford University Press.

Olsen, J.P. (2003) 'Towards a European administrative space?', Journal of European Public Policy, 10 (4), 506-31.

Olsen, J.P. (2007) Europe in Search of Political Order. Oxford: Oxford University Press.

Olsen, J.P. (2010) Governing through Institutional Building. Oxford: Oxford University Press.

Olsen, J.P. (2016) 'Democratic accountability and the terms of political order', European Political Science Review. DOI: 10.1017/S1755773916000084.

Orren, K. and S. Skowronek (2004) The Search for American Political Development. Cambridge: Cambridge University Press.

Padgett, J.F. and W.W. Powell (2012) The Emergence of Organizations and Markets. Princeton, NJ: Princeton University Press.

Pag, S. (1987) 'The relations between the Commission and national bureaucracies', in S. Cassese (ed.) The European Administration. Maastricht: IIAS and EIPA.

Painter, M. and B.G. Peters (eds) (2010) Tradition and Public Administration. Houndmills, Basingstoke, UK: Palgrave Macmillan.

Peters, B.G. (2004) 'Back to the centre? Rebuilding the state', in G. Gamble (ed.) Restating the State. Oxford: Basil Blackwell.

Piattoni, S. (2010) The Theory of Multilevel Governance. Oxford: Oxford University Press.

Poguntke, T. and P. Webb (eds) (2005) The Presidentialization of Politics. Oxford: Oxford University Press.

Raab, J., R.S. Mannak and B. Cambré (2015) 'Combining structure, governance, and context: a configurational approach to network effectiveness', Journal of Public Administration Research and Theory, 25 (2), 479-511.

Raadschelders, J.C.N. (2011) Public Administration. Oxford: Oxford University Press.

Reinalda, B. (2013) 'International organization as a field of research since 1910', in B. Reinalda (ed.) Routledge Handbook of International Organization. London: Routledge.

Rittberger, B. and A. Wonka (2011) 'Introduction: agency governance in the European Union', Journal of European Public Policy, 18, 780-89.

Rochester, M.J. (1986) 'The rise and fall of international organization as a field of study', International Organization, 40, 777-813.

Rokkan, S. (1999) State Formation, Nation-Building and Mass Politics in Europe. Oxford: Oxford University Press. 
Rosenau, J.N. (1969) 'Towards the study of national-international linkages', in J.N. Rosenau (ed.) Linkage Politics: Essays on the Convergence of National and International Systems. New York: The Free Press.

Rothstein, B. (2012) 'Good governance', in D. Levi-Faur (ed.) Oxford Handbook of Governance. Oxford: Oxford University Press.

Saint-Simon, H. (1964) Social Organization, the Science of Man and Other Writings. New York: Harper Torchbooks.

Sartori, G. (1970) 'Concept misconception in comparative politics', American Political Science Review, 64 (4), 1033-53.

Schattschneider, E.E. (1975) The Semisovereign People. Fort Worth, TX: Harcourt Brace Jovanovich College Publishers.

Scheinman, L. (1966) 'Some preliminary notes on bureaucratic relationships in the European Economic Community', International Organization, 20, 750-73.

Simon, H.A. (1957) Administrative Behavior. Second Edition. New York: Macmillan.

Skowronek, S. (1982) Building a New American State. Cambridge: Cambridge University Press.

Stinchcombe, A. (1987) Constructing Social Theories. Chicago: Chicago University Press.

Sverdrup, U. and J. Trondal (eds) (2008) The Organizational Dimension of Politics. Bergen: Fagbokforlaget.

Tamuz, M. and E.T. Lewis (2008) 'Facing the threat of disaster: decision making when the stakes are high', in G.P. Hodgkinson and W.H. Starbuck (eds) The Oxford Handbook of Organizational Decision Making. Oxford: Oxford University Press.

Trondal, J. (2007) 'The public administration turn in integration research', Journal of European Public Policy, 14, 960-72.

Trondal, J. (2010) An Emergent European Executive Order. Oxford: Oxford University Press.

Trondal, J. (2012) 'On bureaucratic centre formation in government institutions: lessons from the European Commission', International Review of Administrative Sciences, 78, 425-45.

Trondal, J. (2014) 'Agencification', Public Administration Review, 74 (4), 545-9.

Trondal, J. (2015) 'The European administrative systems reassessed', in M.W. Bauer and J. Trondal (eds) The Palgrave Handbook of the European Administrative System. Houndmills, Basingstoke, UK: Palgrave Macmillan.

Trondal, J. (2016) 'Advances to the study of international public administration', Journal of European Public Policy, 23 (7): 1097-108.

Trondal, J., M. Marcussen, T. Larsson and F. Veggeland (2010) Unpacking International Organisations. Manchester: Manchester University Press.

Trondal, J. and B.G. Peters (2013) 'The rise of European administrative space: lessons learned', Journal of European Public Policy, 20 (2), 295-307.

Underdal, A. (2008) 'The organizational infrastructure of international environmental regimes', in U. Sverdrup and J. Trondal (eds) The Organizational Dimension of Politics. Bergen: Fagbokforlaget.

Verhoest, K., S.V. Thiel, G. Bouckaert and P. Lægreid (eds) (2012) Government Agencies. Houndmills, Basingstoke, UK: Palgrave Macmillan.

Waldo, D. (1992) The Enterprise of Public Administration. Novato, CA: Chandler \& Sharp Publishers.

Wille, A. (2012) 'The politicization of the EU Commission: democratic control 
and the dynamics of executive selection', International Review of Administrative Sciences, 78, 383-402.

Wille, A. (2013) The Normalization of the European Commission. Oxford: Oxford University Press.

Wilson, J.Q. (1989) Bureaucracy. New York: Basic Books.

Yesilkagit, K. (2011) 'Institutional compliance, European networks of regulation and the bureaucratic autonomy of national regulatory authorities', Journal of European Public Policy, 18 (7), 962-79.

Zürn, M. (2012) 'Global governance as multilevel governance', in D. Levi-Faur (ed.) The Oxford Handbook of Governance. Oxford: Oxford University Press.

\section{FURTHER READING}

Bickerton, C.J. (2012) European Integration. Oxford: Oxford University Press.

Busouic, M., M. Groenleer and J. Trondal (eds) (2012) The Agency Phenomenon in the European Union. Manchester: Manchester University Press.

Christensen, T., A.L. Fimreite and P. Lægreid (2014) 'Joined-up government for welfare administration reform in Norway', Public Organization Review, 14, 439-56.

Christiansen, T. and E. Kirchner (eds) (2000) Europe in Change. Manchester: Manchester University Press.

Curtin, D. and R. Dehousse (2012) 'European Union agencies: tipping the balance?', in M. Busuioc, M. Groenleer and J. Trondal (eds) The Agency Phenomenon in the European Union. Manchester: Manchester University Press.

Dahlström, C., B.G. Peters and J. Pierre (eds) (2011) Steering from the Centre. Toronto: University of Toronto Press.

Dobbels, M. and C. Neuhold (2015) 'Officials "pre-cooking” EU affairs? The role of EP officials in the ordinary legislative procedure (OLP)', in M.W. Bauer and J. Trondal (eds) The Palgrave Handbook of the European Administrative System. Houndmills, Basingstoke, UK: Palgrave Macmillan.

Drake, H. (2000) Jacques Delors. London: Routledge.

Duchêne, F. (1994) Jean Monnet. New York: W. W. Norton \& Company.

Egeberg, M., Å. Gornitzka, J. Trondal and M. Johannessen (2015) 'The European Parliament administration: organizational structure and behavioral implications', in M.W. Bauer and J. Trondal (eds) The Palgrave Handbook of the European Administrative System. Houndmills, Basingstoke, UK: Palgrave Macmillan.

Egeberg, M., M. Martens and J. Trondal (2015) 'EU's subordinated agency administration and the rise of executive power at the European Level', in M.W. Bauer and J. Trondal (eds) The Palgrave Handbook of the European Administrative System. Houndmills, Basingstoke, UK: Palgrave Macmillan.

Egeberg, M., G.F. Schaefer and J. Trondal (2003) 'The many faces of EU committee governance', West European Politics, 26, 19-40.

Egeberg, M. and J. Trondal (2011) 'EU-level agencies: new executive centre formation or vehicles for national control?', Journal of European Public Policy, 18, 868-87.

Egeberg, M. and J. Trondal (2014) 'Nasjonal administrativ suvernitet - myte eller realitet?', in E.O. Eriksen and J.E. Fossum (eds) Det norske paradoks. Oslo: Universitetsforlaget. 
Egeberg, M., J. Trondal and N.M. Vestlund (2014) 'Situating EU agencies in the political-administrative space', ARENA working paper 6.

Fukuyama, F. (2013) 'What is governance?', Governance, 26 (3), 347-68.

Genschel, P. and M. Jachtenfuchs (eds) (2014) Beyond the Regulatory Polity? Oxford: Oxford University Press.

Gornitzka, ̊. and U. Sverdrup (2015) 'The expert-executive nexus in the European administrative system: expert groups and the European Commission', in M.W. Bauer and J. Trondal (eds) The Palgrave Handbook of the European Administrative System. Houndmills, Basingstoke, UK: Palgrave Macmillan.

Groenleer, M. (2009) The Autonomy of European Union Agencies. Delft: Eburon.

Gulbrandsen, C. (2012) Europeanization in a Global Context: A Study of a National Maritime Safety Agency's Work with Global and European Rules. PhD Thesis. University of Oslo.

Haas, E.B. (1958) The Uniting of Europe. Notre Dame, IN: Notre Dame Press.

Hartlapp, M. (2015). 'Politicization of the European Commission: when, how and with what impact?', in M.W. Bauer and J. Trondal (eds) The Palgrave Handbook of the European Administrative System. Houndmills, Basingstoke, UK: Palgrave Macmillan.

Hartlapp, M., J. Metz and C. Rauh (2010) 'The agenda set by the EU Commission: the result of balanced or biased aggregation of positions?', LEQS paper, 21.

Hartlapp, M., J. Metz and C. Rauh (2012) 'Which policy for Europe? Power and conflict over position formation inside the European Commission', paper presented at the workshop 'The transformation of the executive branch of government in Europe', 14-15 June, ARENA, University of Oslo.

Hartlapp, M., J.J. Metz and C. Rauh (2014) Which Policy for Europe? Oxford: Oxford University Press.

Larson, T. (2003) Precooking in the European Union. The World of Expert Groups. A Report to the Expert Group on Public Finance. Stockholm: Ministry of Finance, Ds 2003:016.

Matthews, F. (2012) 'Governance and state capacity', in D. Levi-Faur (ed.) The Oxford Handbook of Governance. Oxford: Oxford University Press.

Murdoch, Z. and J. Trondal (2013) 'Contracted government: unveiling the European Commission's contracted staff', West European Politics, 36 (1), 1-21.

Siedentopf, H. and J. Ziller (1988) Making European Policies Work: The Implementation of Community Legislation in the Member States. Volume I: Comparative Syntheses. EIPA: Bruylant: SAGE.

Wessels, W. (1998) 'Comitology: fusion in action. Politico-administrative trends in the EU system', Journal of European Public Policy, 5 (2), 209-34.

Wessels, W. (2000) Die Öffnung des Staates: Modelle und Wirklichkeit grenzüberschreitender Verwaltungspraxis 1960-1995. Wiesbaden: Vs Verlag FR Sozialwissenschaften. 
Jarle Trondal - 9781786435002 Downloaded from PubFactory at 04/26/2023 02:15:52PM via free access 